\title{
Images of Italy: Cultural Representations in the Peritext of Translational National Anthologies in Sweden
}

Cecilia Schwartz

Stockholm University

È così magica l'Italia, che non si è molto sicuri che esista davvero ${ }^{\mathrm{T}}$ Gabriel García Márquez

This study aims to examine the peritext of translational national anthologies, i.e. collections of translated literary texts from one specific nation published in another. The peritext is sometimes understood as a hybrid space where source and target cultures meet (Elefante, 20I 2, p. II), but it has also been argued that the repackaging of literary texts in new languages and settings tends to reinforce national stereotypes (Sapiro, 2008). Could this be the case for translational national anthologies? In an attempt to answer this question, the current paper analyzes the peritext of anthologies of Italian literature published in Sweden. A corpus of peritexts is examined in order to explore whether cultural images of Italy and Italians are on display in the anthologies. The corpus will thus be analyzed from an imagological perspective, since imagology is the study of literary representations of nations and nationalities, so-called images, that form an imaginated discourse

I "Italy is so magic that one cannot be very sure that it really exists." García Márquez expressed this in an interview from 1987 , now available http://www.ilsole240re.com/art/cultura/20I4-04-I8/sono-realista -puro-e-triste-cerca-magia-20043I_PRN.shtml (accessed I3 May 2020).

How to cite this book chapter:

Schwartz, C. 202 I. Images of Italy: Cultural Representations in the Peritext of Translational National Anthologies in Sweden. In: Jonsson, H., Berg, L., Edfeldt, C. and Jansson, B. G. (eds.) Narratives Crossing Borders: The Dynamics of Cultural Interaction. Pp. 229-253. Stockholm: Stockholm University Press. DOI: https://doi.org/IO.I6993/bbj.k. License: CC-BY 4.0 
(Leerssen 2007). More specifically, the corpus will be compared to the images of Italy and Italians that have been identified from centuries of European travel writing (Beller 2007). Do Swedish anthologies of Italian literature recycle these clichés and national stereotypes? The intersections between translation studies and imagology, on the one hand, and paratexts (focusing on the peritext, the epitext or both) on the other, have recently been highlighted, ${ }^{2}$ but studies that interconnect all three areas - translation studies, imagology and paratexts - are less common.

The corpus, however, is less interesting taken on its own than when viewed in relationship with similar anthologies devoted to the literature of other places. The second part of the article will thus examine whether the results presented in the first part are exclusive to anthologies of Italian literature or if other national literatures undergo similar changes. For this purpose, the peritext of a sample of Swedish translational national anthologies focusing on Poland, Spain and France will serve as a framework for comparison. These nations have been chosen for two reasons. The first reason has to do with the fact that their main national languages (Polish, Spanish and French) occupy different positions in the world system of translations (Heilbron I999): according to this model, French is a central language having a share of ıo percent of the translations worldwide, Spanish - just as Italian and Swedish - enjoy a semi-peripheral position with a share of I to 3 percent of the translations in the world, while Polish is today one of the many peripheral languages with less than I percent of the share of translations ${ }^{3}$. Moreover, choosing the Romance

${ }^{2}$ Even though the comparatist Daniel-Henri Pageaux already in the I990's underscored the use of imagology in studies of cultural transfer (Pageaux I994), the intersection between imagology and translation studies has only recently been more thoroughly examined in the volume Interconnecting Translation Studies and Imagology (Doorslaer et al. 2OI 5), which collects several contributions on the subject. As for the intersection between translation studies and paratexts, see Urpo Kovala's seminal study "Translations, Paratextual Mediation, and Ideological Closure" (I996), which has been followed by a series of interesting works, for instance, Tahir Gürçaglar (2002), Alvstad (20I2), Elefante (20I2), Gil-Bardaji et al. (2OI2), Pellatt (2OI3), Batchelor (20I8).

3 It should be noted however that Polish, until the fall of the Berlin Wall, was a semi-peripheral language (Sapiro, 20I4, p. 85 ). 
countries of France and Spain together with Italy could also reveal prevailing stereotypes of southern Europe. For each of these nations, a sample of five anthologies has been chosen as a means for comparison.

\section{Anthologizing Italy: Forms and Functions of Swedish Collections}

In one of his few articles concerning the international literary field, "Les conditions sociales de la circulation international des idees" (2002), Pierre Bourdieu argued that texts circulate without their national context, obtaining a new signification from the context of reception, which is partly visible in the new packaging. In developing this idea, Gisèle Sapiro claims that recontextualization can be used "to reinforce the more or less stereotypical representations of foreign cultures" (2008, p. I63). What does this recontextualization look like in the case of translational anthologies whose basic selection criterion is a specific nationality? And is it true that texts always lose their original context as they undergo dissemination throughout the world?

To answer these questions, I will analyze what Gerard Genette calls the peritext of 20 anthologies of Italian literature published in Sweden during the years I947-20I 2 (see appendix). The corpus - consisting of titles, covers, blurbs, notes and prefaces - will be examined in order to categorize the form, function and images of Italy and Italians in these anthologies. As Kovala underscores, these are "very heterogeneous elements" ( I 996, p. I 23), consisting in images, photos, illustrations, texts etc., which he conceives both as "problem" and "benefit". From an imagological viewpoint, the advantages predominate, since images, photos and other iconic elements in the peritext interplay with the textual images appearing in blurbs and prefaces.

\section{Form and Function of the Anthologies and Their Peritexts}

The following analysis draws on Genette's assumption that the peritext works as a threshold to the text itself and thus consists of a fruitful method for visualizing the explicit and implicit 
functions of translation anthologies, including the intentions of the anthologist.

Drawing on Helga Essmann's checklist, which has been elaborated to characterize the formal structure of anthologies (I998, p. I 55), the collections included in my corpus could be described as follows: a) bilateral, involving just two nations, Italy and Sweden; b) mostly monolingual: I 2 in Swedish, I in Italian, and 7 bilingual; c) the genre is mainly poetry (I 2 ) and short stories (6), or a mix between prose and poetry (2); d) overall, the peritext is extensive; e) the selection criteria is mainly literary (concerning epoch, genre, etc.), and the arrangement of texts is basically chronological, especially with respect to poetry; $\mathrm{f}$ ) in most cases (I4 of 20), the anthologist is the translator. In addition, the publication of a majority of the anthologies has relied on some kind of involvement - often in terms of financial support - by the Italian Cultural Institute in Stockholm, which suggests a more or less visible presence of the source context in the publications.

The most common type of peritext in my corpus is what Kovala distinguishes as "informative", meaning that it is "devoted to describing the work itself and contextualizing it", often having "long prefaces as well as blurbs and note sections" (Kovala, I996, p. I 27). Interestingly, the informative peritext was almost nonexistent in Kovala's own corpus (Anglo-American translations into Finnish in the years I 890-I930), in which it "was virtually limited to a couple of classics". ${ }^{4}$ The informative peritext tries to bring the text closer to the reader (Kovala, I996, p. I30), and not the other way around, presuming that the reader needs or desires information in order to understand the texts, which implies a vision of a readership with an almost scholarly or educational interest in Italian literature. In the following, I argue that the peritextual elements of the anthologies seem to serve mainly educational,

${ }^{4}$ Based on observations of his corpus, Kovala identifies four different types of "paratexts": the modest paratext, which has only the necessary elements (such as the title, the name of the author etc.); the commercial paratext, the purpose of which is "to advertise other books by the same publisher"; the informative paratext which is "devoted to describing the work and itself and contextualizing it"; the illustrative paratext which has strikingly many illustrations, even within the text itself (Kovala, I996, p. I27). 
preservation and innovation purposes, rather than being motivated by, say, pleasure, accessibility or profit. ${ }^{5}$

\section{Titles and Covers}

The informative element preponderates the titles. In all cases but two, the titles contain a part that Genette calls rhematic, that is, descriptive formal information (I997, p. 86-88). Most commonly, the titles in my corpus are purely rhematic, often indicating the genre, the timespan and the geolinguistic origin of the texts:

Italienska berättare frän Boccaccio till Moravia

'Italian storytellers from Boccaccio to Moravia'6

Modern italiensk lyrik

'Modern Italian poetry'

Italiensk lyrik frän nio sekler

'Italian poetry from nine centuries'

As Genette points out, the use of rhematic titles is a traditional custom that is much less commonly adhered to nowadays (Genette, I997, p. 86). In my corpus, however, rhematic titles are recurrent, at least as a part of the title. There are several cases in which the titles are double, that is, they are both rhematic and thematic, the latter referring to a title that in some way indicates the subject matter of the text (Genette, I997, p. 78). In the following examples, the thematic part precedes the rhematic in the first two examples, and vice versa in the third:

Jorden och döden. Italiensk lyrik $i$ översättning av Estrid Tenggren 'Earth and Death. Italian poetry in translation by Estrid Tenggren'

Kropp mot kropp. Elva samtida italienska poeter

'Body to body. Eleven contemporary Italian poets'

5 Seruya et al. (2013) list several possible functions and purposes for anthologies and collections: pleasure, education, preservation, innovation, protection, structuring, accessibility, dissemination, subjective and profit (2013, p. 5).

${ }^{6}$ All translations from Swedish and Italian are mine, unless otherwise indicated. 
Italien berättar: en förebådande dröm

'Italy tells: a foreboding dream'

Later, in the imagological analysis, I will return to these thematic titles. For now, we can just note that the classical use of purely rhematic titles, on the one hand, and the double title - which is "routine for titles of scholarly works" (Genette, I997, p. 85) - on the other, express, together with the existential connotative value of these titles (earth, death, body, foreboding dream), a sense of serious, not to say highbrow, literature. Moreover, the publishers' names, which in most cases are those of prestigious niche publishers such as Cavefors, Cartaditalia, and Tranan, contribute to the consecration of the publications.

The front covers included in the corpus can most easily be divided into three categories: I) covers without illustrations or photos; 2) covers with illustrations; 3 ) covers with photos. Whichever the three types of cover the book has, they all convey the same sublime and undisguised solemnity.

What about the back covers, which often include blurbs used explicitly for promotional strategies? Are there any blurbs in the sophisticated surroundings of Italian translational anthologies? Well, the answer depends on what is meant by blurb. Many of the publications in my corpus have some kind of text on the back cover or on the flaps, but these texts sometimes simply consist of the names of the included authors or other very laconic information. However, frequent topics in the blurbs that contain more information are: a) the position of Italian literature in Sweden, and b) hints that the book contains a piece of Italy, describing it, for instance, as a "bouquet of short stories" that provides an "irresistible scent of Italy". This last topic stresses the Italianness of the volume and sometimes even makes an appeal to the potential tourist in the reader: "Enchanting, Italy meets the reader in this selection of Italian poetry, in love poems, nature poems and strong moods from cities like Florence and Venice" (ILN). According to Nicky van Es and Johan Heilbron, cultural exchange is relying on the following factors: geographical proximity, related languages, extensive trade transactions, professional contacts, tourism and migration across borders (in Brems et al. 201 5, p. I 5 ). Of these factors, tourism is the only one having an impact on the relation 
between Sweden and Italy and it could be argued that this is what is being reflected in the peritext.

\section{Prefaces}

In the prefaces, selection criteria are refined, and the purposes of the anthology are sometimes presented. Most often, there is the explicit intention to include writers who are "completely unknown in Sweden" or who have "never before been translated into Swedish", which indicates that one of the purposes is innovation, but another is to correct a situation by filling a gap. Altogether, the prefaces in the corpus comment upon several common issues: the Italian literary tradition, the richness of Italian literature, the position of Italian literature in Sweden and the highbrowness of Italian literature.

The prefaces often remind the reader of the length of the Italian literary tradition and of a time when Italy was the center of world literature: when presenting the anthology Italienska berättare (IB) from 1952, Anders Österling recognizes St. Francis of Assisi and Dante as "spiritual teachers and bearers of tradition" (IB, p. 9) for the contemporary writers included in the volume, and he also refers to the early grandeur of Italian literature. In the anthology of Italian Renaissance short stories, Boccaccio is mentioned no fewer than five times, even though none of his texts is included in the volume. Similarly, in my own preface to the volume Italien berättar: en förebådande dröm ('Italy tells: a foreboding dream'), I mention the "ancient roots" of the short story in Italy, referring to the anonymous collection from the thirteenth century, $I l$ Novellino, as well as Boccaccio's Decameron. ${ }^{7}$ All these references to the respectable age of Italy's literature should be understood in the light of what Casanova has described as the international bourse of literary capital, in which age, volume, prestige

7 The decision to include a volume to which I have contributed is not unproblematic. However, since the volume is one of the most important anthologies of Italian prose in recent time, I decided to include it and concentrate on the other elements of the peritext - the cover, title, blurbs and presentations of the authors - without commenting on my own preface. The quote above is the only exception from this rule. 
and language are regarded as literary values (Casanova 2004, pp. I4-I7). Accordingly, another topic that is closely related to the long literary tradition regards the richness (or volume) of Italian literature, which is often expressed with respect to the selection of the texts: the anthology seeks to offer a "broad spectrum" or a "map" of Italian texts, although in some cases the emphasis is on the impossibility of covering everything. Furthermore, the preface writers very often express the desire to offer a "diverse spectrum of society”, “different sides of Italian life” and "today's Italian reality", implicating an extra-literary, educational purpose: through the texts, the reader can learn something about Italy. This becomes more explicit in the recent anthologies published in the new millennium, while older prefaces instead stress the variety of Italian literature included in the volumes. Only in one case, namely the most recent issue, does the preface underscore that the explicit purpose of the anthology is to "promote Italian literature abroad" (TIF, [s.p.]). Rarely do the prefaces highlight such aspects as the universality of the texts, a lack observed in Kovala's study of Finnish paratexts as well (Kovala, I996, p. I37). In this respect, however, three publications deviate from the rest in that they put very little emphasis on the Italianness of the included authors, focusing instead on their aesthetic aspects. Two of the anthologies were translated by Ingamaj Beck and published by Symposion in the I990s, and one was published by Tranan in 2008 .

The weak position of Italian literature in Sweden is a recurring theme in the prefaces, and it is often addressed as a crucial reason for the origin of the anthology. This is actually another issue connecting the very first anthology in the corpus with the most recent ones: "the few famous [writers] are often represented by figures of second or third level in our scale of literary values" laments G. B. Arista (CA, p. 8), while 60 years later his successor asks rhetorically: "What does the cultivated Swedish reader of today know about the contemporary Italian novel?"(TF, p. 5)

Criticism is also directed against the Italian literary system whose poetry, according to Anders Österling, suffers from "pedantry and compulsion toward rules", while the prose remains "provincial and regional" (IB, p. I2). Giacomo Oreglia, on the other hand, accuses Italian literature of being too hegemonic, 
the fruit of an "upper-class culture" (IN, p. 8) that has mainly focused on the formal side of literary expression in order to bow to Benedetto Croce's ideal. Even other prefaces, especially those from the I960s, underscore the necessity of creating a distance with older literary traditions and rigorous conventions. In one of the recent postfaces, the anthology is presented as necessary in order to correct the unequal Italian system: for instance, the struggle for "balance in terms of age, gender and geographic origin" aims to "counteract the imbalance in respect to these categories that pervade the literary world in general and the Italian in particular" (FD, p. 283).

\section{Preface Writers}

The prefaces are, for natural reasons, allographic, i.e. composed by someone other than the author (cf. Genette, I997, pp. 263275). More surprisingly, the preface is rarely written by the translator. Only on four occasions, the preface - if there was one - was authored by the translator, and in two of these cases the name of the translator is Anders Österling, who was one of the most influential and consecrated individuals in the Swedish literary field at the time. ${ }^{8}$ However, the tendency is in line with the general norm in Sweden:

Prefaces are most often written by someone other than the translator. The writers of prefaces usually have a large literary capital (literary critics, literary scholars or authors), and the prefaces usually deal with the books and/or the writers, and not with the translations. (Norberg, 20I2, p. I05)

In accordance to Norberg's observation, the preface writer in the corpus investigated here is often a person within the academic world, which downplays the translators and indicates a clear desire for what Bourdieu calls "institutional consecration". For instance, one of the most prolific translators and anthologizers of

${ }^{8}$ In the twentieth century, the poet Anders Österling (I884-I98I) was one of the foremost translators, mediators and critics of Italian literature in Sweden. He was also a member of the Swedish Academy and its permanent secretary in the years I94I-I964. 
Italian poetry in the I960s, Estrid Tenggren, never presented her three collections herself: two of them lack in prefaces, while the third was written by Paolo Ravacchioli, an Italian lecturer at the University of Lund. Additionally, in I 2 of the anthologies, the prefaces were authored by Italian academics, who were active within universities or other cultural institutions in Italy or Sweden. Once again, the preponderance of Italian preface writers highlights the presence of the source context in the Swedish anthologies. As we have seen in my corpus, the Italian context is actually explicitly present in the prefaces and in the preface writers' perspectives. Moreover, the presence of the source context is sometimes visible even in other parts of the editions: for instance, 6 of the 20 anthologies were published directly by the Italian Cultural Institute in Stockholm, and 2 more publications had as their anthologist Giacomo Oreglia, who was closely connected to the same institute. These editions are often bilingual, not only with respect to the literary texts, but also to the peritext (prefaces, presentation texts and even promotional material are bilingual). The Italian influence is persistent over time: it is significant that the very first anthology in my corpus, from I947, is monolingual, not in Swedish, but in Italian, and promoted by one of the initiative takers of the Italian Cultural Institute in Stockholm, G. B. Arista. The issues of the culture magazine Cartaditalia, both of which were published in 2009, were also promoted by the Cultural Institute, and the publications were bilingual. The strong Italian influence exerted upon these anthologies somewhat contradicts Bourdieu's assumption that literature is exported without its context.

\section{Images of Italy and Italians}

The Italian involvement in the new context, in addition to the tendency to promote Italian literature as highbrow, should all in all constitute poor soil for the growth of national stereotypes and clichés about Italy and Italians, since "the celebration of nationally and ethnically branded 'differences' (...) have been nichemarketed as commercialized 'identities"'(Apter, 20I3, p. 2).

In this respect, imagology offers a fruitful perspective, in that it examines literary representations of nations and nationalities, so-called images that form an imaginated discourse. The latter has been defined as: "a specific set of characterizations and attributes 
outside the area of testable report sentences or statements of fact" (Leerssen, 2007, p. 27). For instance, the statement "France is a republic" is a testable fact, and therefore it is not imaginated, while statements such as "Paris is the capital of French elegance" and "The French are freedom-loving individualists" are imaginated:

Generally, imaginated discourse [a] singles out a nation from the rest of humanity as being somehow different or 'typical', and [b] articulates or suggests a moral, collective-psychological motivation for given social or national features. Imaginated discourse is specifically concerned with the characterological explanation of cultural difference. (Leerssen, 2007, p. 28)

Could stereotypes and simple clichés exist even in a corpus of serious anthologies where preservation, education and innovation are key factors? In order to answer this question, the peritextual corpus has been compared to the images of Italy and Italians that the imagologist Manfred Beller has identified from centuries of European travel writing9 (Beller, 2007, pp. 194-200):

I. Ancient Rome. The admiration for the glory of ancient Rome that reflects adversely on contemporary Italy.

2. Religion. A cluster of negative stereotypes derives from a protestant critique of Catholicism together with literary representations of poverty and banditry. The Gothic novel set in Italy represented the country as "clerical, half-occult, perfidious and dangerous" (2007, p. I95).

3. Fine arts. On the positive side, there is Italians' love of the fine arts, music, theater and, more recently, cinema.

4. Landscape. The image of Italy is largely constructed through the image of its landscapes and city silhouettes, including visual tropes.

5. Region. The image of Italy "remains strongly differentiated by region", especially with respect to the socioeconomic differences between the northern and southern parts of the country.

9 Obviously, these images are constructions and artifacts reflecting a north European view on Italy. The images would probably have looked quite differently if they would have been produced from other perspectives. 
In addition, an image connected to the beauty of Italian landscape and fine arts is the contrast between aesthetic beauty and the inhabitants' immorality - Italy has actually been described as "a paradise occupied by devils". Altogether, these images seem to rely on an ambivalent concept of Italy and Italians. As Beller states, "nineteenth-century travel descriptions continue to list, side by side, positive and negative qualities" (Beller, 2007, p. 197). To what extent do these images appear in the peritext of anthologies of Italian literature? The most apparent image visible in the peritext is the Italian landscape.

Despite their sober designs, the front covers of the anthologies feature some stereotypical visual tropes: palm trees, ancient temples and famous urban silhouettes, as well as cats on roof tiles and laundry hanging from lines between picturesque houses. The sea, the cliffs and, in particular, the red, hot sun are visible even in the more abstract illustrations; these elements are frequent in the covers from the I960s, a period in which the tourism industry in Italy exploded. In addition, the range of colors is often warm, and different combinations of the colors of the Italian flag are frequent. As for the titles, the national and/or linguistic connection is often present via the adjective Italian. In three cases where it is missing, the titles instead refer to the landscape or the sea: Roman trio, Trio in a pastoral landscape, The pearl oyster. ${ }^{10}$ Moreover, in the prefaces, the topography is used as a metaphor for Italian literature, both generally, as in the following formulation: "from the vast expanses of the terra incognita that is contemporary Italian reality" (TF, p. 7) and more specifically, as when one anthologist summarizes his overall impression of the Italian art of storytelling by reproducing a verbal image of the Spanish Steps in Rome (IB, pp. I 2-I3). Another preface assures the reader of obtaining a view that tourists never get: "We will bring [the readers] to [...] a Campania and Sicily that do not know the sea" (TF, p. 7). Furthermore, Italy's uniqueness does not lie only in the beauty of the landscape. A recurring theme in the prefaces and blurbs is the complexity of the country and its literature, which makes them difficult to capture. Therefore, as stated in one of the recent

Io These are my translations of the following titles: Romersk trio, Trio $i$ ett pastoralt landskap and Pärlmusslan. 
anthologies, the book can be used as "a kind of map to explore the vast and manifold land masses that is the contemporary Italian novel” (TIF, [s.p.]). According to Cecilia Alvstad, who has analyzed the peritext of Swedish anthologies of non-European literature, "[ $t$ ] he focus on geography is a discursive strategy employed by publishers, marketing and critics. A complementary strategy is to focus on universal values and common ground" (20I2, p. 87). In the case of Italian anthologies, this complementary strategy is absent, which paradoxically might be explained by the fact that Italy is felt to be so well known to the Swedish reader that the peritext seeks to underscore the differences and local qualities of Italian literature.

The depiction of Italy as a multifaceted and complex nation is projected onto its literature, which is highlighted for its many contrasts. The images based on contrasts are very frequent in all the elements of the corpus, as they appear, for instance, in some of the thematic titles, such as A foreboding dream, a title that connotes threats and promises, a contrast that is further emphasized in the postface:

Italy is a contradictory country - it flaunts its beauty, art and ancient cultural traditions despite its being thoroughly corrupt, poor and heavily commercialized (FD, pp. 284).

Similar suggestive images that should be distinguished from reported facts occur in blurbs and prefaces like the following ones:

We get to know the bad conditions and the abuses of society described through compassion or cold lucidity. We experience excruciating aridity and biting snow. (IN, blurb)

But even in the grayest weather the grenade flower flares as bright red as blood (IB, p. I 2)

The feeling for life is hot, but dark; man's inner problems are not eased by the blue sky (EB, p. I2)

(...) from the dark songs of the uprising to the light tunes of reconciliation (TP, p. 5)

After having stressed the fact that it would be risky to try to "establish some kind of national traits", Anders Österling, in one 
of his prefaces, states that "Italy's voice has shifted greatly; for more than a thousand years it has sounded powerfully expressive and rich in contrast" (IB, p. 9).

Another prominent and contrasting image particularly revealed in the presentations of the authors in the analyzed corpus regards the differences between the northern and the southern part of the country. In these texts, it is frequently reported where the authors were born, especially when they originated in Southern Italy. For instance, in the preface to the anthology of Renaissance short stories, Masuccio Salernitano is described as an "incredibly combative", "impetuous and passionate storyteller" with "reckless and aggressive expressions, and one senses in him the impulsive and biased temper of the Southern Italian" (IRN, p. 9). The description may well be compared to that of Matteo Bandello, who explicitly "represents the North" and is characterized as "extremely broad-minded" with a "far-reaching tolerance" (IRN, p. IO). In one of the anthologies from 2009, which makes a point of involving writers of different classes, genders and geographical origins, only 2 of the I 4 authors were born in Southern Italy. These two writers are tied closely to their origin: Vanessa Ambrosecchio has "given Sicily a voice", while Valeria Parrella's represents Naples, which is described as antithetic: "a chaotic city, full of violence, drug trafficking and crime but also of exclusive art-galleries and dramatic love stories" (FD, p. 289). Obviously, Italy's "internal orientalism" (Schneider I998), i.e. the discursive practices that present Southern Italy as a problem and Italians from the south as different from those of the north, has been imported into the receiving culture.

To conclude, the corpus, even though it is composed only of peritextual material, holds many generic assumptions about Italy, Italians and Italian literature. One common strategy in the earlier anthologies is to connect literature and stereotypes of Italian national character:

"The short, loaded form suits the Italian temper extremely well" (IB, p. I 2)

"The desire to narrate is deeply characteristic of the Italian people" (IB, p. Io) 
“[D'Annunzio] included and represented such an array of typical Italian virtues and vices” (MIL, p. I3)

"The Italians had not, I would dare say, the courage to be futurists" (MIL, p. I7)

This does not continue after the I960s, and the two poetry collections published in the I990s are introduced by prefaces that make no connection at all to Italy or Italians.

To summarize, an imagological analysis of the peritexts in my corpus has shown that Swedish anthologies of Italian literature, despite their elegant designs and the influence of intercultural actors with academic titles, recycle clichés and national stereotypes to a remarkably great extent. They contribute to the long-lived idea that Italy is full of contradictions or, as one of the anthologists puts it, "a multi-faceted country where anything could happen” (FD, p. 284).

\section{Images of Poland, Spain and France in Translational Anthologies}

Is the tendency to underscore the diversity and variety of a nation's literature based on contrasting images exclusive to Italian anthologies? Could it not be a common trope, typical of the anthology genre, which has to do with the very nature of collections, i.e. the aim to present an overview of another nation's literature? In order to answer these questions, the following paragraph analyzes the peritext in a sample of Swedish translational anthologies from three other nations: Spain, France and Poland.

\section{Anthologies of Literature from Poland}

The sample of translational anthologies of Polish literature ranges from years 1972 to 2005 and includes five volumes. ${ }^{\text {I }}$ Already in the titles it can be observed that the thematic parts have

II The anthologies are: Och skuggorna blir längre. En antologi frän krigets Polen ['And the shadows become longer. An anthology from Poland during the war'] (I972); Du måste vittna. Poesi och reportage fràn Polen ['You have to witness. Poetry and reportages from Poland'] (I98I); Frain andra sidan. En antologi med texter av polska författare $i$ Sverige ['From the other side. An anthology with texts by Polish writers in Sweden'] (I997); 
somewhat dark connotations: shadows, war, witness, the other side and umbilical cord in the ground. Differently from the case of oxymoronic Italy, Poland and Polish literature do not seem to be associated with any positive, romantic or sensual aspects at all. ${ }^{12}$ If mysticism, honor, idealism and messianism were elements of Polish auto- and hetero-images before and during Romanticism, it seems clear that the Swedish anthologies from the last decades rather reinforce another old and persistent trope of "victimized, suffering Poland" (Gerrits \& Leerssen, 2007, p. 21 8).

This trope recurs more or less explicitly in the prefaces and/ or back cover blurbs of all the titles of my corpus. Och skuggorna blir längre. En antologi frän krigets Polen (I972) ('And the shadows become longer. An anthology from Poland during the war') is very explicit, stating that the purpose of the volume is to "show what fascism can do to a subdued people" (I972: 9). The dark and tragic aspects of Poland's twentieth-century history are underscored in all the prefaces - the holocaust, Soviet occupation, communism, censorship, persecutions, oppression, exile. Only on one occasion is there a tendency to draw attention to diversity and contrasts. In the poetry collection I7 Polska poeter (2003), Irena Grönberg describes the poets included in the volume as "classicists and everyday-reporters, religious brooders and humourists" (2003, p. 6), and the anthology itself is referred to as a poetic archipelago with manifold islands. It is noteworthy, however, that these varieties regard the poets and their poetic residence, and not the Poles nor Poland.

Even though the sufferings of the Poles, unfortunately, are historical facts rather than just imaginated discourse, the strong focus on the nation's suffering should also be conceived as the choice of a certain trope. This becomes more evident in comparison with the Italian corpus, in which the two decades of the fascist regime, the German occupation and the terrorism in the I970s and '80s are only rarely mentioned in the peritexts. I argue that the difference between the selected images and tropes in

I7 polska poeter ['I 7 Polish poets'] (2003); Polen berättar: Navelsträngen $i$ jorden ['Poland tells: the umbilical cord in the ground'] (2005).

${ }^{12}$ This is reflected in the selection of the colors for the covers as well: they are all soberly blue, beige, white or grey, sometimes with a small red detail, which could signal both communism and the red of the Polish flag. 
the case of Poland and Italy, at least to some extent, has to do with Swedish hetero-images of the two nations: Italy as a colorful and oxymoronic dreamland; Poland as a gray and suffering country, victim of many oppressors. Obviously, the chosen tropes also imply an auto-image of Sweden as the homeland of moderation (in contrast to Italy) and freedom (in contrast to Poland).

\section{Anthologies of Literature from Spain}

The inventory of Swedish anthologies from Spain showed a surprisingly narrow timespan: of the six volumes found, five were published in the years I959-I966. ${ }^{13}$ The explanation for this abandonment seems clear enough: beginning in the I970s, Swedish translations from Spanish changed focus from Spain to Latin America, whose literature had been rather neglected in Sweden. In the period from I959 to I966, however, there were five anthologies focusing on authors from Spain, and all but one of these are marked by the political situation during the Franco regime. Three of these anthologies use the peritext - title, cover design and preface - to highlight the desperate political dimension of the publication: Siälen tjuter ('the soul is howling') from I959 is a poetry anthology with a black and red cover; Det svarta Spanien ('the black Spain') is also red and black, while Vredgade vittnen ('furious witnesses') is adorned with a cover in black and white, representing, in an expressionist manner, the face of a crying or shouting person.

All publications but one have prefaces in which the Spanish Civil War and the Franco dictatorship are addressed in the prefaces. One of the collections, Spanska berättare (1963), is distinguished from the rest in that it does not even mention civil war, fascist regime, censorship or oppression. The anthologist, university lecturer Mateo Pastor-López, instead focuses on the tradition of the Spanish short story, which, according to him, contributed

ז3 The examined anthologies are: Siälen tjuter ['The soul is howling'] (I959), Spanska berättare ['Spanish storytellers'](I963), Moderna spanska noveller ['Modern Spanish short stories'](I964), Det svarta Spanien ['Black Spain']( I966), Vredgade vittnen ['Furious witnesses']( I966). The sixth volume, Generation 27! (I996), which has not been taken into consideration, was an anthology of poetry from Spain, focusing on authors from the early $20^{\text {th }}$ century, the so-called "generation of ' 27 ". 
largely to subsequent and more elaborate works of short stories such as Boccaccio's Decameron and Chaucer's Canterbury Tales. Interestingly, this is the only volume that draws on national clichés about Spain and Spaniards: firstly, the red-yellow-black front cover is adorned with an illustration of a woman with a mantilla and a hand fan, presenting a proud look to a young, elegantly dressed man pictured from behind, and secondly, the preface disseminates typically north European clichés about southern temperament, for instance, when Pastor-López states that the short story receives its form from the "authors' temperament and feeling", and, therefore, "the objective, emotionless and impersonally coloured short story is less recurrent in Spain" (1963, p. 8).

The same focus on great contrasts of personalities, as observed in the Italian corpus, is not as visible in the anthologies focusing on Spain. On one occasion, however, the preface writer says, about Lorca: "the conflict between worship of life and sense of death, that seem so typically Spanish" (r966, p. 9). Another difference that can be observed comparing the Italian corpus to the Spanish is that the former is less anchored in political and historical events than the corpus of texts from Spain.

\section{Anthologies of Literature from France}

The centrality of France as a cultural and literary nation in Sweden is confirmed when considering the number of anthologies focusing on the country, especially in comparison with Spain. While many translational anthologies from Spanish originate from Latin-American countries, France has maintained its hegemony as a source text nation over other Francophone nations. The most common theme in the prefaces of the six anthologies in the corpus $^{\mathrm{I} 4}$ is definitely the richness of French literature in comparison to Swedish literature. This issue is often explicitly pronounced: "the over rich field of French poetry" (I95I, p. 5), "French literature is so tremendously much older and richer than ours that

${ }^{14}$ En bukett fransk lyrik ['a bouquet of French poetry'](I95I), Berömda franska berättare ['Famous French storytellers'](I957), Boulevarder och fågelsträck ['Boulevards and flight of birds']( I984), Franska landskap frän Ronsard till Rimbaud ['French landscapes from Ronsard to Rimbaud'] (2003), Frankrike berättar: Där vi står nu ['France tells: Where we stand now'] (20I4). 
an orientation is hardly allowed to be made" (1957, p. 7), "the richness and diversity that the French poetry possesses" (2003, p. I 2), "the great river of the last decade's poetry in France" (I984, p. 6), "[the anthology] do not claim to cover the flora of Frenchlanguage writers today" (20I4, p. Io).

Even though the most common picture of France in the examined volumes is that of an extremely wealthy literary nation, there are two prefaces that also underscore this powerful nation's negative sides. In the anthology entitled Boulevarder och fägelsträck ('boulevards and flight of birds'), from I984, the preface focuses on the dominance of Paris and French writers' scheming for the critics of the capital: "It is a world filled with envy and wheedling. And it is a very small world, that of the Parisian litterateurs, not at all larger than its Swedish counterpart"(I984, p. 9). Similarly, in the most recent collection, Frankrike berättar: Där vi står nu ('France tells: Where we stand now'), from 20I4, it is claimed that France's former glory is precariously slanting.

The prefaces of French anthologies are the only ones among the chosen nations that thematize the contrasts in a way similar to that which was observed for their Italian counterparts. Prominent Swedish poet Gunnar Ekelöf is the one who draws the most from the contrasts of France and French people in his preface to the anthology Berömda franska berättare ('Famous French storytellers'), dedicating a great part of the text to establish the French "national character" (1957, p. 9). In order to accomplish this task, he describes the nation as both Catholic and free-minded, and, paradoxically, both conservative and modern (I957, pp. 8-10). Ekelöf also states that "it is the country of opposites" (I957, p. 9). Furthermore, in the aforementioned volume from I984, the title of which already indicates a contrast between the boulevards of Paris and the flight of birds in the countryside, it is stressed in the preface that the anthology aims to embrace "the tension between the big city and the countryside, the myths about both, the contrasts between them, the simultaneousity" (I984, p. 9). Finally, the anthology from $20 \mathrm{I}_{4}$ is another example of how the shifting character of France is thematized:

A France, which with its history of colonial great power and revolutionary heritage, its faltering economy and political 
stagnation, its countryside under depletion and its cities under expansion, continuously fluctuate and changes colour depending on where you look. And who is doing it. And from where (20I4, pp. 9-10).

\section{Concluding Remarks}

This survey has shown that literature does not always travel without its source context, as Bourdieu once claimed. Except for France, the Swedish translational national anthologies in my corpus include publications that are explicitly and evidently influenced by mediators originating from the source text nation. However, this influence turns out to be much more frequent in the Italian case, due to the recurrent contributions from the Italian Cultural Institute in Stockholm. This indicates the importance of the Italian state and its 83 cultural institutes spanning the globe in promoting and sustaining literary circulation - a phenomenon that definitely merits more scholarly attention than it has received in the past.

When it comes to the imagological analysis of Italian anthologies, the results suggest that elements surrounding the text the peritext - tend to reinforce national stereotypes. Out of 20 anthologies, only one does not draw at all from already existing cultural representations of Italy and Italians. Actually, all the images listed by Beller emerge to a more or less great extent in my corpus. This indicates that even when the source context is present, national clichés continue to be recycled. The image that preponderates, however, is that Italy is a contradictory nation, fascinating because of its many contrasts. I consider this focus on contrasts - which, interestingly enough, has not subsided with time - as the perpetuation of the antithetic images of Italy listed by Beller. Actually, I suggest that the image of Italy as a nation of contrasts is a trope in itself, which recurs even when the author seems aware of the difficulty of categorizing literature in terms of nationality (cf. IB, p. 9).

The same oxymoronic trope was much less common in the anthologies focusing on Poland and Spain, which also concentrated more frequently on issues regarding politics. Instead of dwelling 
on the suffering of Italian people in the last century, the analyzed peritexts chose other perspectives, which might have to do with the great presence of the source culture in the publications. On the other hand, less emphasis on the nation's politics unite Italian and French peritexts, focusing on the richness of these national literatures and sometimes even formulating critical opinions on their literary hegemony. To summarize, Italian literature is presented and treated more similarly to the central language area (French) than it is to the (semi-)peripheral languages Spanish and Polish. The images of Italy and Italians are, however, the most stereotypical, and their focus on contrasting elements perpetuate a tenacious vision of Italy as an anomaly.

\section{References}

Alvstad, C. (2OI2). “The Strategic Moves of Paratexts: World Literature through Swedish Eyes." Translation Studies 5 (I), pp. 78-94.

Apter, E. (2013). Against World Literature. On the Politics of Untranslatability. London, New York: Verso.

Batchelor, K. (2018). Translation and Paratexts. London \& New York: Routledge.

Beller, M. \& Leerssen, J. (eds.). (2007). Imagology. The Cultural Construction and Literary Representation of National Characters. A Critical Survey. Amsterdam, New York: Rodopi.

Beller, M. (2007). "Italians", in Beller, M. \& Leerssen, J. (eds.) Imagology. The Cultural Construction and Literary Representation of National Characters. A Critical Survey. Amsterdam, New York: Rodopi, pp. 194-200.

Bourdieu, P. (2002). "Les conditions sociales de la circulation internationale des idées," Actes de la recherché en sciences sociales, vol I45, décembre 2002, pp. 3-8.

Brems, E., Réthelyi, O., van Kalmthout T. (eds.) (20I7). Doing Double Dutch. The International Circulation of Literature from the Low Countries (pp. 67-9I). Leuven: Leuven University Press.

Casanova, P. (2004). The World Republic of Letters. Cambridge, Massachusetts: Harvard University Press. 
van Doorslaer, L., Flynn, P. and Leerssen, J. (eds.) (2015). Interconnecting Translation Studies and Imagology. Amsterdam/ Philadelphia: John Benjamins.

Elefante, C. (20I2). Traduzione e paratesto. Bologna: Bononia University Press.

Essmann, H. (1998). "Weltliteratur Between Two Covers: Forms and Functions of German Translation Anthologies," in MuellerVollmer, K. and Irmscher, M. (eds.) Translating Literatures, Translating Cultures. New Vistas and Approaches in Literary Studies. Berlin: Erich Schmidt Verlag, pp. I49-163.

Genette, G. (1997). Paratexts: Thresholds of interpretation. Cambridge: Cambridge University Press.

Gerrits, A. \& Leerssen, J. (2007). Poles, in Beller, M. and Leerssen, J. (eds.) Imagology. The Cultural Construction and Literary Representation of National Characters. A Critical Survey. Amsterdam, New York: Rodopi. pp. 216-2I9.

Gil-Bardají, A., Orero, P. and Rovira-Esteva, S. (eds.). (20I2). Translation Peripheries: Paratextual Elements in Translation. Bern: Peter Lang.

Heilbron, J. (I999). "Towards a Sociology of Translation. Book Translations as a Cultural World-System," European Journal of Social Theory 2/4, pp. 429-444.

Jansen, H. (2015). "Bel Paese or Spaghetti Noir? The Image of Italy in Contemporary Italian fiction Translated into Danish," in van Doorslaer, L., Flynn, P. and Leerssen, J. (eds.) Interconnecting Translation Studies and Imagology (eds.).Amsterdam/Philadelphia: John Benjamins, pp. I63-I79.

Kovala, U. (I996). "Translations, Paratextual Mediation, and Ideological Closure," Target 8:I, pp. I I9-I 47.

Leerssen, J. (2007). "Imagology: History and method," in Imagology. The Cultural Construction and Literary Representation of National Characters. A Critical Survey. (Beller, M. \& Leerssen, J., eds.). Amsterdam, New York: Rodopi, pp. 17-32.

Norberg, U. (20I2). "Literary Translator's Comments on Their Translations in Prefaces and Afterwords: The Case of 
Contemporary Sweden," in Gil-Bardají, A., Orero, P. and Rovira-Esteva, S. (eds.) Translation Peripheries: Paratextual Elements in Translation. Bern: Peter Lang, pp. IoI-I I 6.

Pageaux, D-H. (I994). La littérature générale et comparée. Paris: Colin.

Pellatt, V. (ed.) (2013). Text, Extratext, Metatext and Paratext in Translation. Cambridge: Cambridge Scholars Publishing.

Sapiro, G. (2008). "Translation and the Field of Publishing. A Commentary on Pierre Bourdieu's 'A Conservative Revolution in Publishing'." Translation Studies I:2, pp. I 54-I 66.

- (2014). "The Sociology of Translation. A New Research Domain," in Bermann, S. and Porter, C. (eds.) A Companion to Translation Studies. Chichester: Wiley Blackwell, pp. 82-94.

Schneider, J. (1998). Italy's Southern Question. Orientalism in One Country. London: Bloomsbury Academic.

Seruya, T. et al. (2013). Translation in Anthologies and Collections. Benjamins Translation Library. Amsterdam: John Benjamins.

Tahir Gürçaglar, Ş. (2002). “What Texts don’t Tell. The Uses of Paratexts in Translation Research," in Hermans, T. (ed.) Crosscultural Transgressions. Research Models in Translation Studies II. Historical and Ideological Issues. Manchester UK and Northampton MA: St Jerome Publishing, pp. 44-6o.

\section{Appendix: anthologies of Italian literature published in Sweden}

See Appendix table on next page. 


\begin{tabular}{|c|c|c|c|c|c|c|c|c|c|c|c|c|c|c|c|}
\hline 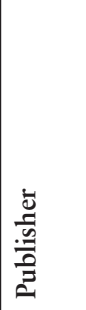 & 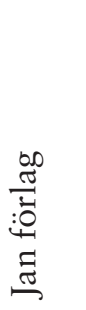 & 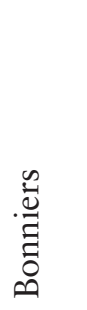 & 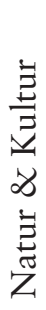 & 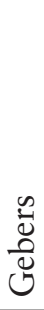 & 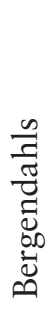 & 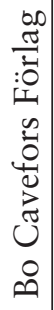 & 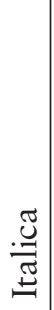 & 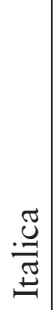 & 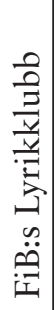 & 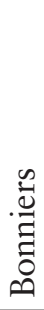 & 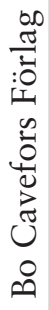 & 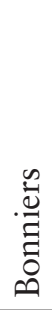 & 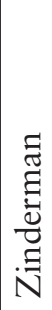 & $\begin{array}{l}\frac{1}{0} \\
\text { की } \\
0 \\
\text { है } \\
\text { ह }\end{array}$ & $\begin{array}{l}\text {.0 } \\
\text { के } \\
0 \\
\text { है } \\
\text { क }\end{array}$ \\
\hline 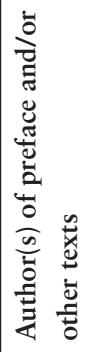 & 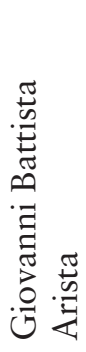 & 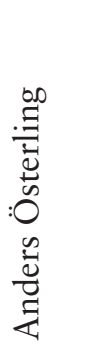 & 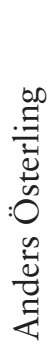 & 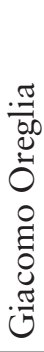 & 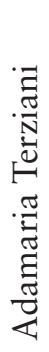 & 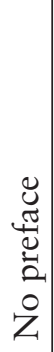 & 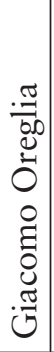 & 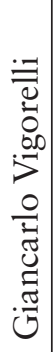 & 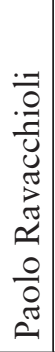 & 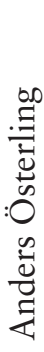 & 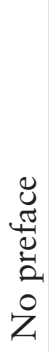 & 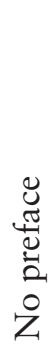 & 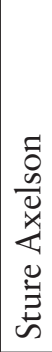 & 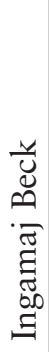 & 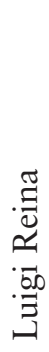 \\
\hline 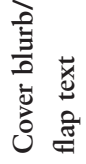 & $\stackrel{\circ}{Z}$ & $\stackrel{\mathscr{E}}{\nu}$ & $\stackrel{\circ}{Z}$ & $\stackrel{\infty}{\infty}$ & $\stackrel{\infty}{\infty}$ & $\stackrel{\infty}{\nu}$ & $\stackrel{\mathscr{E}}{\nu}$ & $\stackrel{\infty}{\nu}$ & $\stackrel{\infty}{\infty}$ & $\stackrel{\infty}{\infty}$ & $\stackrel{\infty}{\infty}$ & $\stackrel{\circ}{Z}$ & $\stackrel{\infty}{\infty}$ & $\stackrel{\infty}{\infty}$ & $\stackrel{\mathbb{Z}}{\nu}$ \\
\hline ठ̃ & 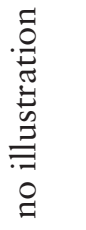 & 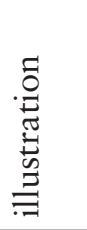 & 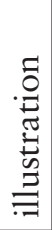 & 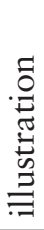 & 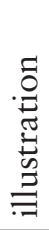 & 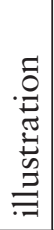 & 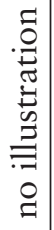 & 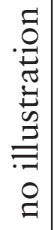 & 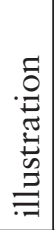 & 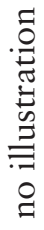 & 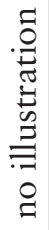 & 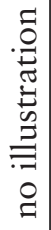 & 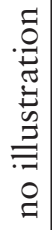 & $\begin{array}{l}\stackrel{0}{0} \\
\frac{1}{2} \\
2\end{array}$ & $\begin{array}{l}0 \\
\stackrel{0}{0} \\
\text { 일 }\end{array}$ \\
\hline 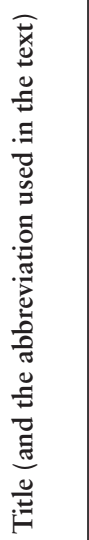 & 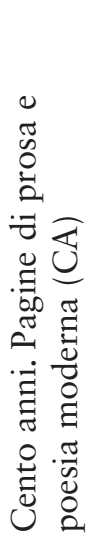 & 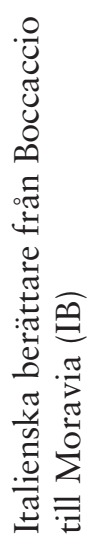 & 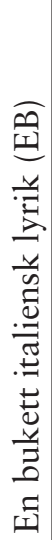 & 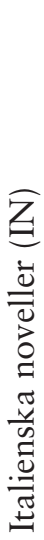 & 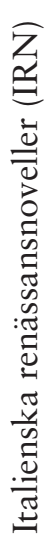 & 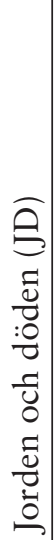 & 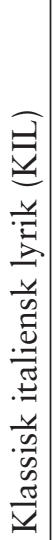 & 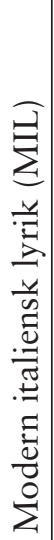 & 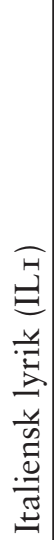 & 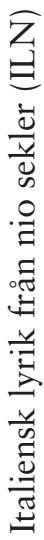 & 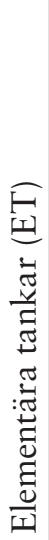 & 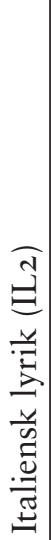 & 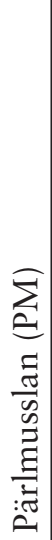 & 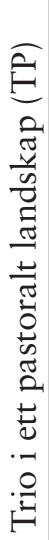 & 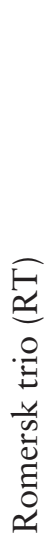 \\
\hline$\underset{\nabla}{\tilde{\Xi}}$ & $\stackrel{\nwarrow}{\stackrel{テ}{\sigma}}$ & $\stackrel{n}{\sim}$ & $\stackrel{+}{\sim}$ & $\underset{6}{6}$ & $\begin{array}{l}\text { 음 } \\
\text { - }\end{array}$ & 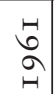 & 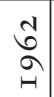 & 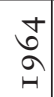 & 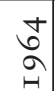 & $\underset{\sigma}{n}$ & $\begin{array}{l}\infty \\
ٌ \\
\ddots\end{array}$ & $\begin{array}{l}0 \\
\hat{\Omega} \\
\Omega\end{array}$ & $\begin{array}{l}+ \\
\hat{a}\end{array}$ & $\hat{\alpha}$ & $\stackrel{\infty}{\curvearrowright} \underset{\sigma}{\sigma}$ \\
\hline
\end{tabular}




\begin{tabular}{|c|c|c|c|c|}
\hline 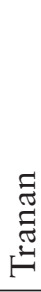 & 㫊 & 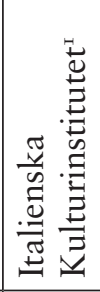 & 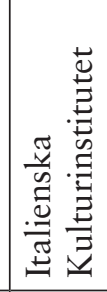 & 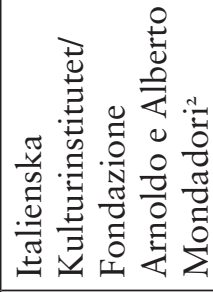 \\
\hline 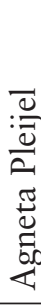 & 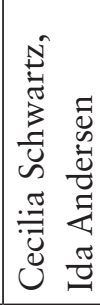 & 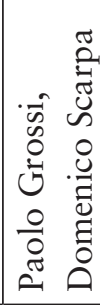 & 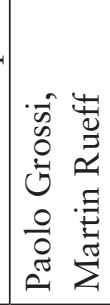 & $\begin{array}{c}\vec{w} \\
0 \\
0 \\
0 \\
0 \\
0 \\
0 \\
\tilde{v}\end{array}$ \\
\hline$\stackrel{\circ}{Z}$ & $\stackrel{\infty}{\sim}$ & $\stackrel{\circ}{Z}$ & $\stackrel{\circ}{Z}$ & $\stackrel{\infty}{\infty}$ \\
\hline 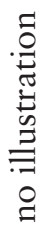 & $\begin{array}{l}0 \\
0 \\
0 \\
\frac{1}{2}\end{array}$ & $\begin{array}{l}0 \\
\stackrel{0}{0} \\
0 \\
\\
2\end{array}$ & 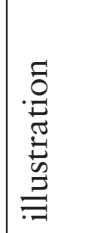 & 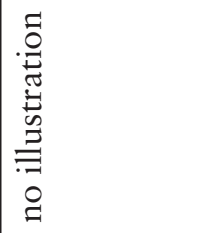 \\
\hline 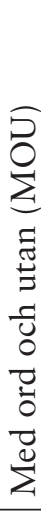 & 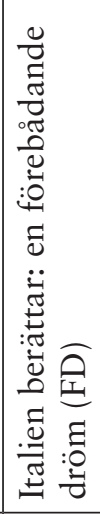 & 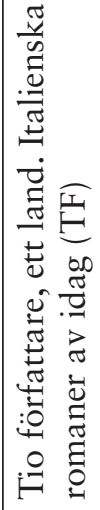 & 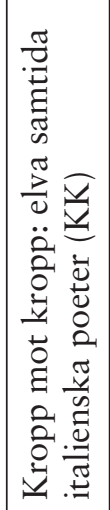 & 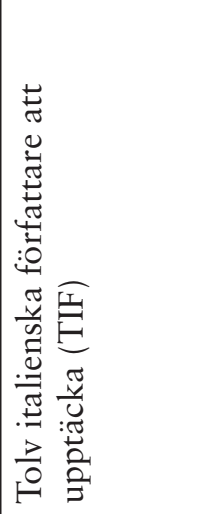 \\
\hline $\begin{array}{l}\infty \\
0 \\
0 \\
\text { d }\end{array}$ & ठ̊. & $\begin{array}{l}\text { Оे } \\
\text { ठ্ }\end{array}$ & $\begin{array}{l}\text { ठे } \\
\text { ठ্ }\end{array}$ & $\frac{4}{4}$ \\
\hline
\end{tabular}

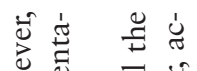

岕

元范 元

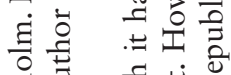

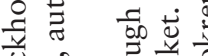

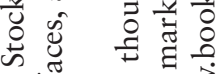

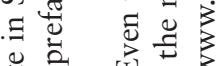

리

ت

छ

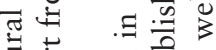

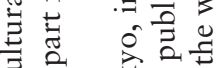

उे 항 항

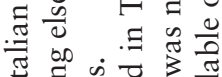

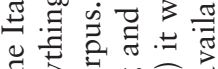

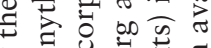

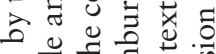

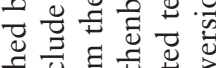
क ज

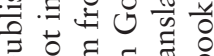

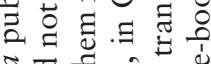

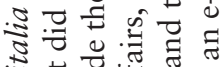
की 월 S. 齿

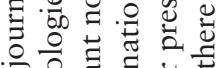

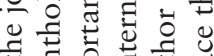

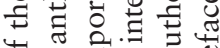
눙 年.

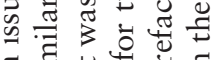
完.

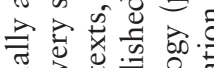
政

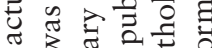

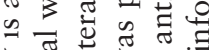
앙 응. 을 它

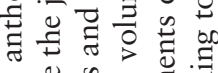

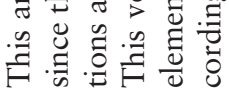

